\title{
BENEFITS OF OZONE THERAPY IN THE TREATMENT OF FOOT ULCERS IN PEOPLE WITH DIABETES MELLITUS
}

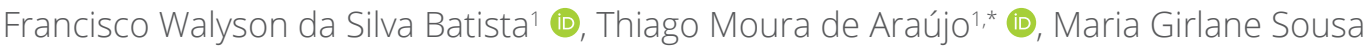 \\ Albuquerque Brandão² (1), Vanessa Aguiar Ponte ${ }^{3}$ (I)
}

\begin{abstract}
Objective: To identify the benefits of ozone therapy in the treatment of foot ulcers in people with diabetes mellitus. Method: Literature review carried out in the CINAHL, Cochrane Library, LILACS, PUBMED, SCiELO, SCOPUS and Web of Science databases in the period between April and May 2020. In each database, the controlled descriptors were delimited in the Science Descriptors of Health and Medical Subject Headings, keywords defined: Ozone (Ozone), Diabetic Foot (Diabetic foot), with the help of the Boolean operator AND. Results: 14 primary studies were selected. Most studies have level II evidence, published in English, in different journals, from different parts of the world. 15 benefits of ozone therapy for the treatment of foot ulcers were identified, with a predominance of increased granulation tissue and intensification in the progress of tissue repair. Conclusion: The use of ozone therapy has shown several benefits in the progress in tissue repair of foot ulcers in people with diabetes, increased granulation tissue, promoted antiseptic and bactericidal activities, preventing oxidative stress.
\end{abstract}

DESCRIPTORS: Ozone. Diabetic foot. Therapeutics. Stomatherapy.

\section{BENEFÍCIOS DA OZONIOTERAPIA NO TRATAMENTO DE ÚLCERAS NOS PÉS EM PESSOAS COM DIABETES MELLITUS}

\section{RESUMO}

\begin{abstract}
Objetivo: Identificar os benefícios da ozonioterapia no tratamento de úlceras nos pés de pessoas com diabetes mellitus. Métodos: Revisão de literatura realizada nas bases de dados CINAHL, Cochrane Library, LILACS, PUBMED, SciELO, SCOPUS e Web of Science, no período de abril a maio de 2020. Em cada base de dados, os descritores controlados foram delimitados nos Descritores em Ciências da Saúde e Medical Subject Headings, definidas as palavras-chaves: Ozônio (Ozone) e Pé Diabético (Diabetic foot), com auxílio do operador booleano AND. Resultados: Houve a seleção de 14 estudos primários. A maioria dos estudos possui nível II de evidência, publicados em inglês, em distintos periódicos, oriundos de diversas partes do mundo. Foram identificados 15 benefícios da ozonioterapia para o tratamento de úlceras nos pés, com predomínio de aumento do tecido de granulação e intensificação no progresso do reparo tecidual. Conclusão: O uso da ozonioterapia apresentou diversos benefícios no progresso do reparo tecidual de úlceras nos pés em pessoas com diabetes, aumentando o tecido de granulação, promovendo atividades antissépticas e bactericidas e prevenindo o estresse oxidativo.
\end{abstract}

DESCRITORES: Ozônio. Pé diabético. Terapêutica. Estomaterapia.

1. Universidade da Integração Internacional da Lusofonia Afro-Brasileira - Instituto de Ciências da Saúde - Redenção (CE), Brazil.

2. Universidade de São Paulo - Escola de Enfermagem de Ribeirão Preto - Ribeirão Preto (SP), Brazil.

3. Universidade Federal do Ceará - Departamento de Enfermagem - Fortaleza (CE), Brazil.

*Correspondence author: thiagomoura@unilab.edu.br

Section Editor: Manuela de Mendonça F Coelho

Received: Apr. 2021, 25 | Accepted: Jun. 2021, 11

How to cite: Batista FWS; Araújo TM; Brandão MGSA; Ponte VA. Benefits of ozone therapy in the treatment of foot ulcers in people with diabetes mellitus. ESTIMA, Braz. J. Enterostomal Ther., 2021, 19: e1821. https://doi.org/10.30886/estima.v19.1090_IN 


\section{BENEFICIOS DE LA OZONOTERAPIA EM EL TRATAMENTO DE LAS ÚLCERAS DEL PIE EN PERSONAS COM DIABETES MELLITUS}

\section{RESUMEN}

Objetivo: Identificar los beneficios de la ozonoterapia en le tratamiento de las úlceras del pie em personas con diabetes mellitus. Método: Revisión de la literature realizada en las bases de datos CINAHL, Cochrane Library, LILACS, PUBMED, SciELO, SCOPUS y Web of Science en le período de abril a mayo de 2020. En cada base de datos los descriptors controlados se delimitaron en los Descriptores de Ciencias Salud y Medicina. Encabezados de material, palabras claves definidas: ozono (ozono), pie diabético (pie diabético), con la ayuda del operador booleano AND. Resultados: Hubo una selección de 14 estudios primarios. La mayoría de los estudios tienen evidencia de nivel II, publicada en inglés, en diferentes revistas, de diferentes partes del mundo. Se identificaron 15 beneficios de la ozonoterapia para el tratamiento de las úlceras del pie, con predominio del aumento del tejido de granulación e intensificación en el avance de la reparación tisular. Conclusión: El uso de la ozonoterapia present varios beneficios en el avance en la reparación tisular de las úlceras del en personas con diabetes, aumento del tejido de granulación, promovió actividades antisépticas y bactecidas, previniendo el estrés oxidative.

DESCRIPTORES: Ozono. Pie diabético. Terapia. Estomaterapia.

\section{INTRODUCTION}

Ozone therapy is a therapeutic resource that uses the ozone molecule as its main component, and its application can be combined with oxygen in different concentrations. Manipulated since World War II, ozone has been touted as an adjuvant therapy for wound care ${ }^{1}$.

This therapy is regulated by health surveillance agencies in several countries, such as Germany, China, Cuba, Spain, Greece, Portugal, Russia and Turkey². In Brazil, ozone therapy is regulated by a Bill of the Federal Senate (227/2017), which authorizes the prescription of ozone therapy as a complementary treatment within the Unified Health System (Sistema Único de Saúde-SUS $)^{3}$.

The Federal Council of Nursing (Conselho Federal de Enfermagem-COFEN), through Normative Opinion No. 001 of 2020, it recognized and regularized ozone therapy as a complementary practice that can be carried out by nurses, under the condition that they are qualified. The agency guides professionals to reach 120 hours in courses on the subject. In nursing, technology can be applied to improve outcomes to treat injuries of different etiologies, thus raising the quality of care for patients affected with skin lesions ${ }^{4}$.

A class of injury that can be treated with this type of adjuvant therapy is foot ulcers in people with diabetes mellitus (DM), which can involve several sensory, motor and foot deformities, which can aggravate and condition necrosis and/or serious infections, the result of incorrect and deficient actions in the prevention of this clinical condition ${ }^{5}$.

Foot ulcers are the main cause of hospital admissions within the group of people affected with DM, therefore, it is the disease that promotes higher costs to health services, and the risk of non-traumatic amputations and even death ${ }^{6}$. The estimated number of deaths from diabetes and its complications in 2019 is 4.2 million people. Scary index that expresses the equivalence of one death every 8 seconds 7 .

Thus, the treatment of foot ulcers in people with DM can benefit from the adjuvant action of ozone therapy, since the technology has oxidizing and disinfecting properties1. Clinical studies carried out in Iran and Russia identified a reduction in infection and amputations in the feet of people with DM who underwent treatment with ozone ${ }^{8,9}$.

Knowing the benefits of new technologies and improving existing protocols can contribute to reducing the rates of amputations caused by DM complications, with the diabetic foot being one of the most relevant causes. Ozone therapy as an adjunct technology is an important milestone for health. Knowing its benefits and the best way to apply it to foot ulcers is essential. This generates optimization in the handling of technology, better quality assistance and significantly important 
advances for the scientific field, arousing curiosity and epistemological considerations to be investigated by the scientific community. This study aims to identify the benefits of ozone therapy in the treatment of foot ulcers in people with DM.

\section{METHOD}

\section{Type of study}

This is a Literature Integrative Review (IR). In this type of study, a methodological approach is used, in which it is intended to carry out a review to fully understand the phenomenon examined. A combination of data from the literature and other deliberations is carried out, such as: definition, review of theories and analysis of questions about problems of peculiar models ${ }^{10}$. The textual corpus was built through scientific productions that report benefits of the application of ozone therapy in the treatment of diabetic foot ulcers.

\section{Methodological framework}

The integrative review followed six steps: I) Construction of the research problem; II) Sample screening from descriptors; III) Collection of relevant information; IV) Analysis of information related to the researched topic; V) Appreciation and interpretation of the collected results; and VI) Data exposure ${ }^{11}$.

\section{Methodological path}

In this process, the PICO strategy was used: where $\mathrm{P}$ refers to the population, patient or problem (people with diabetic foot ulcers), I intervention (treatment with ozone therapy), element $\mathrm{O}$ refers to the outcome (beneficial effects of ozone therapy in the treatment of the lesion of interest in this study), whereas element $C$, of comparison between intervention or group, was not used due to the type of review ${ }^{12}$. Therefore, the guiding question of this study, based on the PICO method, is: "What are the benefits of ozone therapy in the treatment of diabetic foot ulcers?".

\section{Data extraction source}

The bibliographic survey took place between April and May 2020. To search for primary studies, seven databases were consulted: CINAHL (EBSCO), Cochrane Library (COCHRANE), Literatura Latino-americana e do Caribe em Ciências da Saúde (LILACS), National Library Of Medicine (PUBMED), Scientific Electronic Library Online (SciELO), Sciverse Scopus (SCOPUS), Web of Science, directly on their search engines or through the CAPES Periodical Portal. In each database, the controlled descriptors were delimited in the Descritores em Ciências da Saúde (DESC) and Medical Subject Headings (MESH), and defined the keywords: Ozônio (Ozone) and Pé Diabético (Diabetic foot). For the LILACS and SciELO databases, the search strategy used was "Ozônio AND Pé diabético". In the CINAHL, COCHRANE, PUBMED, SCOPUS and Web of Science databases, the strategy used was "Ozone AND Diabetic foot".

\section{Data collection}

There was no delimitation in the dates of publication of the studies, which followed in a timeless search. The delimited eligibility criteria were primary studies, which addressed therapeutic procedures in the treatment of diabetic foot ulcers with ozone therapy, available free of charge in full and published in Spanish, English and Portuguese. Publications that did not meet the guiding question of the study, studies with lesions of other etiologies, review articles, studies with animal species or in vitro, repeated theses, dissertations, letters to the editor or articles unavailable in the databases were excluded. 
The extraction of data from primary studies was performed with the subsidy of an instrument developed and submitted to face and content validation ${ }^{13}$.

The level of evidence was defined according to the classification: level I - meta-analysis of controlled and randomized studies; level II - experimental study; level III - quasi-experimental study; level IV - descriptive/non-experimental study or with a qualitative approach; level V - case report or experience; level VI - consensus and expert opinions ${ }^{14}$.

Data analysis of the integrative review was elaborated descriptively. Each study included was analyzed in detail by the authors and two summary tables were prepared, containing the following information: the first table contains the title of the articles, source database, author citation, year and country of production, purpose of the study, sample, type of study and level of study; in the second, the organization is done by name of author(s), year of publication, frequency of application of ozone therapy, form of application and main result found by the research.

\section{Ethical aspects}

All scientific productions used in the research were duly cited and referenced, respecting copyright.

\section{RESULTS}

The initial search identified 210 records in the selected databases. After reading the title and abstract, 168 articles that did not meet the eligibility criteria were excluded, as they presented a different theme.

42 articles were selected for reading the title and abstract. There were 14 articles excluded due to duplication and, thus, 28 articles were selected for full reading. Among the 28 studies evaluated as fully eligible, 12 were incomplete and/or inaccessible, 1 article was carried out with an animal model and another was inconsistent with the study's guiding question, which were excluded. Thus, 14 primary studies comprised the sample of this IR, according to the flowchart described in Fig. 1.

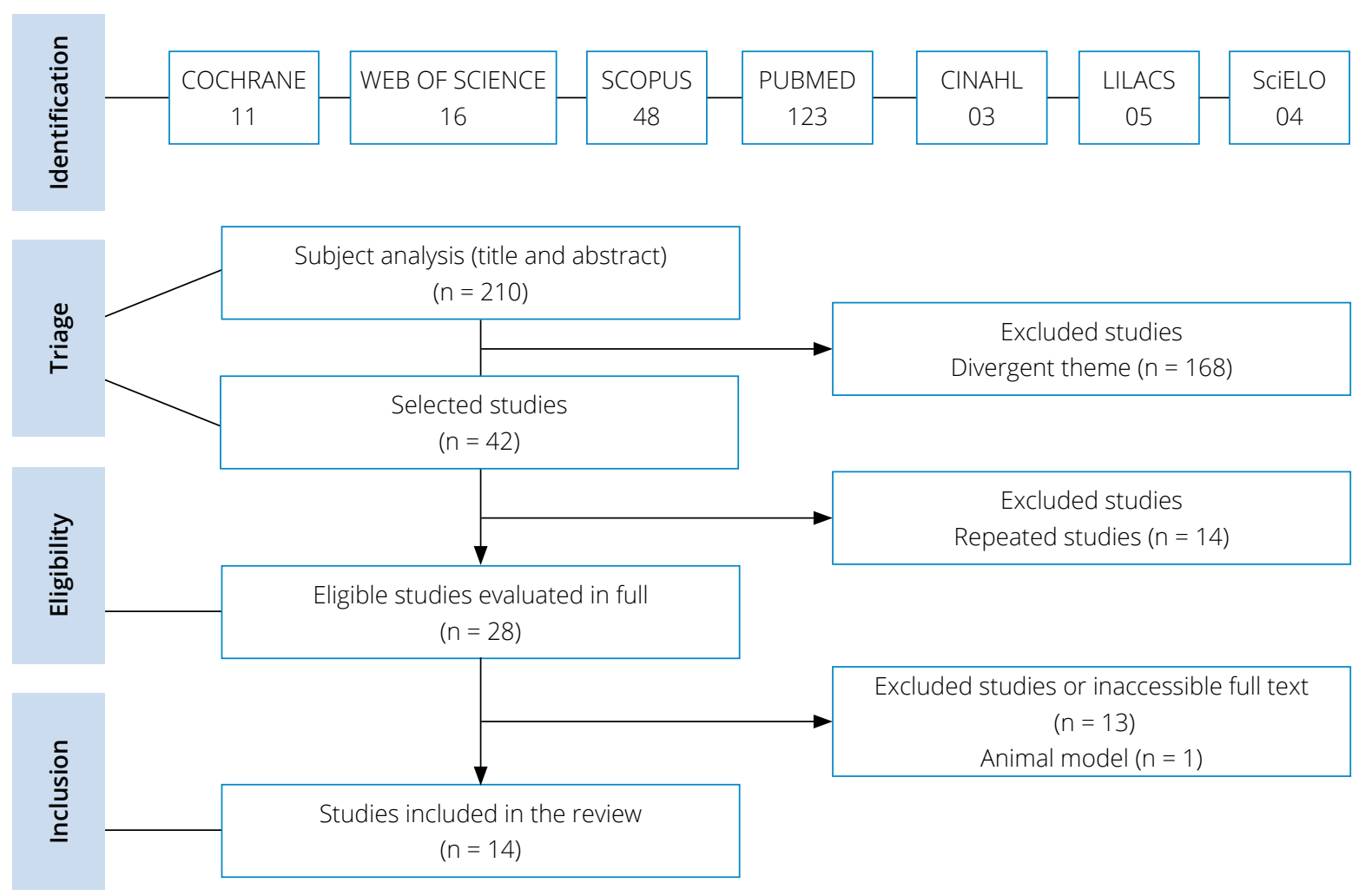

Figure 1. Flowchart of the selection of studies according to PRISMA. Redenção (CE) - 2021. 
The final analysis included 14 studies with 1,148 people with diabetic foot ulcers, which aimed to identify the safety and/or efficacy of ozone therapy in the treatment of foot ulcers. Most studies have level II evidence, published in English ( $=9)$ in different journals, from different parts of the world, which are described in Table 1.

Table 1. Characterization of the studies included in the review. Redenção (CE) - 2021.

\begin{tabular}{|c|c|c|c|c|c|}
\hline$N^{\circ}$ & Title (Data base) & $\begin{array}{c}\text { Authors } \\
\text { (Year)/ } \\
\text { Country }\end{array}$ & Objective & Sample & $\begin{array}{l}\text { Type of } \\
\text { Study/LE }\end{array}$ \\
\hline
\end{tabular}

Comprehensive treatment of diabetic hallux gangrene with

1 lower extremity vascular disease: A case report (WEB OF SCIENCE)
To describe the case of a diabetic patient with gangrene of the hallux and

Gao et al., $\quad$ vascular disease of the lower limbs, 201915/China treated with surgical debridement, 01 patient $\quad$ Case study/ ozone therapy and vascular interventional surgery.

\begin{tabular}{|c|c|c|c|c|c|}
\hline 2 & $\begin{array}{l}\text { Efficacy of comprehensive ozone } \\
\text { therapy in diabetic foot ulcer } \\
\text { healing (COCHRANE LIBRARY) }\end{array}$ & $\begin{array}{l}\text { Izadi et al., } \\
\text { 2019//ran }\end{array}$ & $\begin{array}{l}\text { Identification of the safety and efficacy } \\
\text { of ozone in healing foot ulcers in } \\
\text { patients with diabetes. }\end{array}$ & $\begin{array}{c}200 \\
\text { patients }\end{array}$ & $\begin{array}{l}\text { Randomized } \\
\text { clinical trial/ } \\
\text { ॥ }\end{array}$ \\
\hline 3 & $\begin{array}{l}\text { Evolución de las úlceras de pie } \\
\text { diabético con el tratamiento } \\
\text { mixto de Heberprot-P®y } \\
\text { ozonoterapia (LILACS) }\end{array}$ & $\begin{array}{l}\text { Martínez et al., } \\
\text { 201916/Cuba }\end{array}$ & $\begin{array}{l}\text { Determining the evolution of diabetic } \\
\text { foot ulcers with Heberprot- } P ® \text { mixed } \\
\text { treatment and ozone therapy. }\end{array}$ & $\begin{array}{c}323 \\
\text { patients }\end{array}$ & $\begin{array}{l}\text { Retrospective } \\
\text { and descriptive } \\
\text { study/ } \\
\text { IV }\end{array}$ \\
\hline 4 & $\begin{array}{l}\text { Ozone Therapy in the } \\
\text { Comprehensive Treatment } \\
\text { of Diabetic Foot Syndrome } \\
\text { (SCOPUS) }\end{array}$ & $\begin{array}{l}\text { Teuvov et al., } \\
20179 \text { /Russia }\end{array}$ & $\begin{array}{c}\text { Evaluate the effectiveness of the } \\
\text { application of ozonized solutions in } \\
\text { the complex treatment of diabetic foot } \\
\text { syndrome. }\end{array}$ & $\begin{array}{c}37 \\
\text { patients }\end{array}$ & $\begin{array}{l}\text { Randomized } \\
\text { clinical trial/ } \\
\text { ॥ }\end{array}$ \\
\hline 5 & $\begin{array}{l}\text { Ozone therapy effectiveness in } \\
\text { patients with ulcerous lesions due } \\
\text { to diabetes mellitus (SCOPUS) }\end{array}$ & $\begin{array}{l}\text { Rosul; Patskan, } \\
\text { 201617/ } \\
\text { Ukraine }\end{array}$ & $\begin{array}{c}\text { Study the effectiveness of ozone use } \\
\text { in complex therapy in patients with } \\
\text { diabetic foot. }\end{array}$ & $\begin{array}{c}47 \\
\text { patients }\end{array}$ & $\begin{array}{l}\text { Randomized } \\
\text { clinical trial/ } \\
\text { ॥ }\end{array}$ \\
\hline 6 & $\begin{array}{l}\text { Atención multidisciplinaria con } \\
\text { terapia avanzada y de recurso a } \\
\text { pacientes con pie diabético en } \\
\text { Mayabeque (LILACS) }\end{array}$ & $\begin{array}{l}\text { Barrios et al., } \\
2015^{18} / \text { Cuba }\end{array}$ & $\begin{array}{c}\text { Describe the model of care for } \\
\text { patients with diabetic foot used in the } \\
\text { consultation. }\end{array}$ & $\begin{array}{c}113 \\
\text { patients }\end{array}$ & $\begin{array}{l}\text { Retrospective } \\
\text { and descriptive } \\
\text { study/ } \\
\text { IV }\end{array}$ \\
\hline 7 & $\begin{array}{l}\text { Beneficios de la intervención con } \\
\text { ozonoterapia em pacientes con } \\
\text { pie diabético neuroinfeccioso } \\
\text { (SciELO) }\end{array}$ & $\begin{array}{l}\text { Duarte et al., } \\
2014^{19} / \text { Cuba }\end{array}$ & $\begin{array}{l}\text { Evaluate the benefits of ozone } \\
\text { intervention in type } 2 \text { diabetic } \\
\text { patients suffering from neuroinfectious } \\
\text { diabetic foot. }\end{array}$ & $\begin{array}{c}150 \\
\text { patients }\end{array}$ & $\begin{array}{l}\text { Randomized } \\
\text { clinical trial/ } \\
\text { ॥ }\end{array}$ \\
\hline 8 & $\begin{array}{l}\text { Increased Growth Factors Play a } \\
\text { Role in Wound Healing Promoted } \\
\text { by Noninvasive Oxygen-Ozone } \\
\text { Therapy in Diabetic Patients with } \\
\text { Foot Ulcers (WEB OF SCIENCE) }\end{array}$ & $\begin{array}{l}\text { Zhang et al., } \\
2014^{20} / \text { China }\end{array}$ & $\begin{array}{l}\text { Evaluate the effects of ozone therapy } \\
\text { on healing and expression of VEGF, } \\
\text { TGF- and PDGF in early stage wounds } \\
\text { after treatment. }\end{array}$ & $\begin{array}{c}50 \\
\text { patients }\end{array}$ & $\begin{array}{l}\text { Randomized } \\
\text { clinical trial/ } \\
\text { ॥ }\end{array}$ \\
\hline 9 & $\begin{array}{c}\text { Ozone Therapy in Diabetic } \\
\text { Foot and Chronic, Nonhealing } \\
\text { Wounds (SCOPUS) }\end{array}$ & $\begin{array}{l}\text { Fathi; } \\
\text { Mawsoufn; } \\
\text { Viebahn- } \\
\text { hänsler } \\
\text { 2012²1/Egypt }\end{array}$ & $\begin{array}{l}\text { To study the effectiveness of using } \\
\text { ozone in complex therapy in patients } \\
\text { with diabetic foot. }\end{array}$ & $\begin{array}{c}63 \\
\text { patients }\end{array}$ & $\begin{array}{c}\text { Case series/ } \\
\vee\end{array}$ \\
\hline
\end{tabular}


Table 1. Continuation...

\begin{tabular}{|c|c|c|c|c|c|}
\hline $\mathrm{N}^{\circ}$ & Title (Data base) & $\begin{array}{l}\text { Authors } \\
\text { (Year)/ } \\
\text { Country }\end{array}$ & Objective & Sample & $\begin{array}{l}\text { Type of } \\
\text { Study/LE }\end{array}$ \\
\hline 10 & $\begin{array}{c}\text { Efficacy of Ozone-Oxygen Therapy } \\
\text { for the Treatment of Diabetic } \\
\text { Foot Ulcers (WEB OF SCIENCE) }\end{array}$ & $\begin{array}{l}\text { Wainstein et } \\
\text { al., 201122/ } \\
\text { Israel }\end{array}$ & $\begin{array}{l}\text { To examine the effectiveness } \\
\text { of non-invasive ozone and oxygen } \\
\text { therapy in the treatment of } \\
\text { diabetic foot ulcers. }\end{array}$ & $\begin{array}{c}61 \\
\text { patients }\end{array}$ & $\begin{array}{c}\text { Randomized } \\
\text { clinical trial/ } \\
\text { ॥ }\end{array}$ \\
\hline 11 & $\begin{array}{c}\text { Ozonoterapia como tratamento } \\
\text { adjuvante na ferida de pé diabético } \\
\text { (LILACS) }\end{array}$ & $\begin{array}{l}\text { Cardoso, et al., } \\
\text { 201023/Brazil }\end{array}$ & $\begin{array}{l}\text { To report the treatment of a } \\
\text { diabetic patient, atherosclerotic, with a } \\
\text { history of infected ulcer associated with } \\
\text { osteomyelitis in the fourth right toe, } \\
\text { with blood perfusion, } \\
\text { incompatible with healing. }\end{array}$ & 1 patient & $\begin{array}{c}\text { Case study/ } \\
\text { V }\end{array}$ \\
\hline 12 & $\begin{array}{c}\text { Major Ozonated } \\
\text { Autohemotherapy in Chronic } \\
\text { Limb Ischemia with Ulcerations } \\
\text { (SCOPUS) }\end{array}$ & $\begin{array}{l}\text { Monte; Der- } \\
\text { Zee; Bocci } \\
\text { 200524/ } \\
\text { Netherlands }\end{array}$ & $\begin{array}{c}\text { Report the beneficial } \\
\text { effects of autohemotherapy } \\
\text { with ozone in two patients } \\
\text { affected by painful and untreatable } \\
\text { leg ulcers. }\end{array}$ & 2 patients & $\begin{array}{c}\text { Case study/ } \\
\text { V }\end{array}$ \\
\hline 13 & $\begin{array}{c}\text { Therapeutic efficacy of ozone } \\
\text { in patients with diabetic foot } \\
\text { (COCHRANE LIBRARY) }\end{array}$ & $\begin{array}{l}\text { Martínez- } \\
\text { Sánchez et al., } \\
\text { 200525/Cuba }\end{array}$ & $\begin{array}{l}\text { Evaluate the effectiveness of } \\
\text { ozone in the treatment of patients } \\
\text { with type } 2 \text { diabetes, suffering } \\
\text { from complications in diabetic feet } \\
\text { and its effects on oxidative stress, } \\
\text { hyperglycemia and some markers of } \\
\text { endothelial damage, to compare ozone } \\
\text { with antibiotic therapy. }\end{array}$ & $\begin{array}{c}100 \\
\text { patients }\end{array}$ & $\begin{array}{c}\text { Randomized } \\
\text { clinical trial/ } \\
\text { ॥ }\end{array}$ \\
\hline 14 & $\begin{array}{c}\text { Efecto del ozono sobre la } \\
\text { activación plaquetaria en } \\
\text { pacientes diabéticos tratados con } \\
\text { ozonioterapia: informe } \\
\text { preliminar (SCOPUS) }\end{array}$ & $\begin{array}{l}\text { Batista et al., } \\
2001^{26 / C u b a}\end{array}$ & $\begin{array}{l}\text { Check whether or not } \\
\text { there was inhibition of platelet } \\
\text { aggregation in people with } \\
\text { ischemic or neuroinfective } \\
\text { diabetic foot after treatment } \\
\text { with ozone. }\end{array}$ & 9 patients & $\begin{array}{c}\text { Case study/ } \\
\text { V }\end{array}$ \\
\hline
\end{tabular}

$\mathrm{LE}=$ Level of evidence; VEGF = vascular endothelial growth factor; TGF- $\beta=$ transforming growth factor beta; $P$ DGF = platelet derived growth factor.

Table 2 shows the application protocols for ozone therapy and the results achieved with the use of this therapy. The application frequency varied according to the assessment of the lesion; the application time ranged from two weeks to months. Different methods of application of ozone therapy were used, such as local application, intravenous, rectal insufflation and intralesional injection, in different concentrations of ozone.

The most used method was the local application, through bagging of ozone in the lesion. Only in the intralesional injection method were there negative results. In other studies, there was an improvement in the tissue repair process, granulation, epithelialization, pain reduction, antisepsis, reduction in the need for major and minor amputations, improvement in blood glucose levels, in addition to bactericidal and fungicidal effects.

Table 3 shows the 16 benefits of ozone therapy reported in the studies analyzed. The most frequent benefits were progress in tissue repair and granulation, antiseptic and bactericidal effects, prevention or inhibition of oxidative stress, and improvement in vascularization and glycemic control. 
Table 2. Frequency distribution, form of application and main result of the studies. Redenção (CE) - 2021.

\begin{tabular}{ccc}
\hline $\begin{array}{c}\text { Authors } \\
\text { and year of } \\
\text { publication }\end{array}$ & Application frequency & Form of application \\
\hline
\end{tabular}

Local application of a pouch filled with

Gao et al., $2019^{15} /$ China

Application of ozone daily, during the dressing. concentrated ozone, positioned on the foot, for 20 minutes. The patient started with an ozone concentration of $30 \mu \mathrm{g} / \mathrm{mL}$. After two consecutive treatments the ozone concentration gradually increased by $5 \mu \mathrm{g} / \mathrm{mL}$.
Improves granulation tissue growth and maintains a relatively

clean wound environment.
Local treatment using special bags with ozone, for 30 minutes. Ozonized gel (Ozolive) was applied

Ozone application twice

Izadi et al., a week (interval of at 20198/Iran least 24 h) until wound closure. to the wounds every 12 hours and then dressed with sterile gauze. Subcutaneous injection of ozone-oxygen was performed around the wound. In systemic use, patients received a mixture of ozone and oxygen, via rectal or intravenous administration.
Cure and reduction of infections and amputations, which has been shown to be effective in ozone therapy in curing diabetes ulcers and reducing infections and amputations.

\begin{tabular}{cc}
$\begin{array}{c}\text { Martínez } \\
\text { et al., 201916/ } \\
\text { Cuba }\end{array}$ & $\begin{array}{c}\text { Daily application, from } \\
\text { Monday to Friday, once } \\
\text { a day (in the morning), } \\
\text { for two weeks. }\end{array}$ \\
\hline $\begin{array}{c}\text { Teuvov et al., } \\
\text { Daily } / \text { Russia }\end{array}$ & $\begin{array}{c}\text { duration of treatment } \\
\text { varied according to } \\
\text { the patients' general } \\
\text { conditions. }\end{array}$
\end{tabular}

Local treatment, by placing the affected limb in a plastic bag, sealed with plaster and filled with an ozone/oxygen mixture at an ozone concentration between 50 and $60 \mathrm{mg}$.
Improved wound healing and decreased number of minor amputations.
Application of local and general ozone sessions. For general ozone therapy, $200 \mathrm{~mL}$ of $0.9 \%$ saturated ozone solution of sodium chloride was injected intravenously, with an ozone concentration of 800-1000 mcg/L. Local ozone therapy included daily wound dressings and the introduction of ozonized saline solution with concentrations of 3-4 mg/L.
Improvement in the general condition of patients, decrease in endotoxicosis rates, acceleration of regenerative processes in purulent wounds, decrease in the number of microbial bodies in spots, reduction in bed days.

\begin{tabular}{|c|c|c|c|}
\hline $\begin{array}{l}\text { Rosul; } \\
\text { Patskan, } \\
\text { 201617/ } \\
\text { Ukraine }\end{array}$ & $\begin{array}{l}\text { Daily application for } 12 \\
\text { to } 14 \text { days. }\end{array}$ & $\begin{array}{l}\text { Application of } 200 \mathrm{~mL} \text { of ozonized physiological } \\
\text { saline solution at an ozone concentration of } \\
1000 \text { to } 1300 \mathrm{mcg} / \mathrm{L} \text { intravenously. For local } \\
\text { therapy, ozone dissolved in } 0.9 \% \mathrm{NaCl} \text { and } \\
\text { ozonized sea buckthorn oil at a concentration } \\
\text { of } 4000 \mathrm{mcg} / \mathrm{L} \text { were used. }\end{array}$ & $\begin{array}{l}\text { There was an improvement in the } \\
\text { healing process, improvement in } \\
\text { lipid peroxidation and antioxidant } \\
\text { protection indices, with a } \\
\text { reduction in hospital stay and } \\
\text { treatment of the diabetic foot. }\end{array}$ \\
\hline $\begin{array}{l}\text { Barrios et al., } \\
2015^{18} / \text { Cuba }\end{array}$ & $\begin{array}{c}\text { Application of } 12 \\
\text { sessions, with unknown } \\
\text { interval. }\end{array}$ & $\begin{array}{l}\text { Local application with plastic bags (concentration } \\
\text { of } 40-50 \mathrm{mgL}^{-1} \text { of } \mathrm{O}^{3} \text { volume ) and systemic } \\
\text { application by rectal insufflation }(150 \mathrm{~mL} \text { at a } \\
\left.\text { concentration of } 30-40 \mathrm{mgL}^{-1}\right) \text {. }\end{array}$ & $\begin{array}{l}\text { Lesions fully healed, improves the } \\
\text { healing process with bactericidal } \\
\text { and fungicidal effects of ozone. }\end{array}$ \\
\hline $\begin{array}{l}\text { Duarte et al., } \\
2014^{19} / \text { Cuba }\end{array}$ & $\begin{array}{l}\text { Application for } 21 \text { days, } \\
\text { with omitted interval. }\end{array}$ & $\begin{array}{l}\text { Local application with plastic bags } \\
\text { (concentration of } 40-50 \mathrm{mgL}^{-1} \text { of } \mathrm{O}^{3} \text { volume } \\
\text { depending on foot size) until filling, and } \\
\text { systemically by rectal insufflation. }\end{array}$ & $\begin{array}{c}\text { Improved healing } \\
\text { rate and aseptic state, } \\
\text { with re-epithelializing edges } \\
\text { and granulation tissue; the } \\
\text { wounds were fully healed } \\
\text { and there were no major } \\
\text { amputations. }\end{array}$ \\
\hline $\begin{array}{l}\text { Zhang et al., } \\
\text { 2014²0/China }\end{array}$ & $\begin{array}{l}\text { Application of ozone for } \\
30 \text { minutes for } 20 \text { days. }\end{array}$ & $\begin{array}{l}\text { Topical oxygen and ozone therapy with } \\
52 \mu \mathrm{g} / \mathrm{mL} \text { of ozone (total volume: } 20-50 \mathrm{~mL} \text { ) in } \\
\text { a special pouch for } 30 \text { minutes, using an ozone } \\
\text { generating device (Humazon Promedic, German), } \\
\text { in addition to the standard treatment. }\end{array}$ & $\begin{array}{l}\text { Improves healing rate and VEGF, } \\
\text { TGF- } \beta \text { and PDGF. }\end{array}$ \\
\hline
\end{tabular}


Table 2. Continuation...

\begin{tabular}{|c|c|c|c|}
\hline $\begin{array}{c}\text { Authors } \\
\text { and year of } \\
\text { publication }\end{array}$ & Application frequency & Form of application & Main result \\
\hline $\begin{array}{l}\text { Fathi; } \\
\text { Mawsoufn; } \\
\text { Viebahn- } \\
\text { hänsler } \\
\text { 2012²1/Egypt }\end{array}$ & $\begin{array}{l}\text { Varied applications until } \\
\text { reaching maximum } \\
\text { benefit in the treatment } \\
\text { process. }\end{array}$ & $\begin{array}{l}\text { Rectal insufflation and application of topical } \\
\text { ozonized solutions (in one case, ozonized water } \\
\text { compresses were used and in another ozonized } \\
\text { oil, in addition to application). }\end{array}$ & $\begin{array}{l}\text { Improvement in healing, size } \\
\text { of the area with granulation } \\
\text { tissue and tissue vascularization. } \\
\text { Improvement in glycemic } \\
\text { control, in addition to reports of } \\
\text { improvement in heart condition. }\end{array}$ \\
\hline
\end{tabular}

The treatment was divided into two phases: 1st - Application 4 times a week for a maximum of 4 weeks or until Wainstein granulation of $50 \%$ of et al., 201122/ the wound. The break Israel did not exceed 1 day 5 days a week. 2nd - Application twice in 1 week to complete the 12 weeks of treatment.
Local ozone therapy through hermetic sealing and ozone/oxygen gas mixture introduced into the sealing system.
Significant improvement in tissue repair of the diabetic foot compared to conventional treatment, especially when protocols for foot ulcers with a surface $<5$ centimeters are administered.
Topical therapy through baths (hydroozonotherapy- Ozonomatic () , followed by dressings with ozonized oil. In the 10th week of treatment, a gaseous mixture (bagging) of oxygen and ozone was introduced, before hydro-ozone therapy.
The treatment promoted antiseptic properties, which improved local oxygenation due to induced neovascularization and accelerated tissue repair. et al., 201023/

Brazil weeks. Does not report application interval and frequency.
Self-hemotherapeutic: gaseous mixture composed of medicinal oxygen (96\%) and ozone (4\%). The oxygenated ozone associated with the blood was reinfused into the donor for 20 minutes.
Improvement of pain, swelling, healing and promotion of a sense of well-being. Autohemotherapy resulted in complete healing of difficult-to-heal ulcers.

Netherlands at intervals of two to three days, for several months.
Rectal administration (10 mg ozone dose, ozone concentration: 50 mg/L). In local therapy, the lesion was covered with a plastic bag, sealed in the leg, under vacuum with ozone at a concentration of $60 \mathrm{mg} / \mathrm{L}$ for 1 hour. For topical therapy, ozonized sunflower oil was used.
Ozone treatment improved glycemic control, prevented oxidative stress, and levels of organic peroxides and activated superoxide dismutase were normalized.
Rectal administration of $200 \mathrm{~mL}$ of ozone at a concentration of 50 to $80 \mathrm{mg} / \mathrm{L}$ for

Batista et al., Daily application for 10 200126/Cuba
1 to 2 min, combined, in some cases, with local application of plastic bags with ozone at a concentration of $80 \mathrm{mg} / \mathrm{L}$, for a maximum period of 2 hours.
There was a reduction in the percentage of platelet aggregation at the end of ozone therapy compared to initial values.

VEGF = vascular endothelial growth factor; TGF- $\beta$ = transforming growth factor beta; PDGF = platelet-derived growth factor . 
Table 3. Benefits of using ozone therapy in the treatment of diabetic foot. Redenção (CE) - 2021.

\begin{tabular}{|c|c|}
\hline Benefits of using ozone therapy & Articles \\
\hline Accelerates tissue repair and increases granulation tissue & $1 ; 2 ; 3 ; 4 ; 5 ; 6 ; 7 ; 8 ; 10 ; 11 ; 12 ; 13 ; 14$ \\
\hline Antiseptic and bactericidal properties & $1 ; 2 ; 3 ; 4 ; 6 ; 7 ; 10 ; 11 ; 12$ \\
\hline Prevents or inhibits oxidative stress & $2 ; 4 ; 5 ; 7 ; 8 ; 12 ; 13 ; 14$ \\
\hline Improves tissue vascularization & $1 ; 5 ; 7 ; 10 ; 11 ; 12 ; 13$ \\
\hline Improves glycemic control & $4 ; 5 ; 6 ; 8 ; 10 ; 14$ \\
\hline Decreases amputation rates & $2 ; 3 ; 7 ; 10 ; 12$ \\
\hline Improves the pain & $4 ; 5 ; 7 ; 11 ; 13$ \\
\hline Reduces hospital stay & $3 ; 5 ; 7 ; 14$ \\
\hline Indicates systemic improvement beyond the injury & $2 ; 4 ; 5 ; 10$ \\
\hline Causes a feeling of well-being & $5 ; 10 ; 13$ \\
\hline Reduces edema & $4 ; 5 ; 13$ \\
\hline Reduces bed time & $4 ; 5$ \\
\hline Multiplies collagen fibers & 8 \\
\hline Increases the expression of VEGF, TGF- $\beta$ and PDGF proteins. & 8 \\
\hline Reduces the percentage of platelet aggregation & 15 \\
\hline
\end{tabular}

VEGF = vascular endothelial growth factor; TGF- $\beta$ = transforming growth factor beta; PDGF = platelet-derived growth factor .

\section{DISCUSSION}

The analysis of the results of the studies included in the review allowed the identification of compliance regarding the use of ozone therapy as an adjuvant for the treatment of foot ulcers in people with DM.

Ozone therapy proved to be a beneficial therapy, with a predominant outcome of increased granulation tissue and advances in the tissue repair process. Furthermore, studies suggest that ozone therapy has antiseptic and bactericidal properties, acts to prevent or inhibit oxidative stress, improves the level of pain, tissue vascularization and glycemic control. Cuban studies report that such characteristics can significantly contribute to the reduction of hospital admissions ${ }^{16,19,25}$.

Ozone therapy also showed signs of systemic improvement and promoted physiological benefits in the user's body as a whole. A study in Iran identified as a benefit of ozone therapy the reduction in sedimentation of erythrocytes, c-reactive protein and reduced fasting blood glucose ${ }^{8}$. This data demonstrates that the therapy under study can provide the patient with secondary outcomes that help in conducting foot ulcer healing.

Studies in Russia, Ukraine and Egypt corroborate the beneficial results of the use of ozone not only for ulcers, since this therapy secondarily induces the normalization of the white blood cell count, with a reduction in segmented leukocytes, an increase in the number of lymphocytes and monocytes, and characteristic of immunomodulation, which is documented as a transition from degenerative to regenerative inflammatory effect ${ }^{9,17,21}$.

Systemic ozone therapy also reduced reports of complaints of thirst, dry mouth sensation, polyuria, and increased catalase activity, in addition, there is a record of clinical cardiac improvement ${ }^{17,21}$. Generating observational data with a larger group of patients and adopting a research model with controlled clinical trials may extend the confidence interval and reveal other benefits or reactions not yet known. Clinical studies in Israel and Iran showed that the study group that used ozone therapy had a significantly higher rate in the proportion of complete wound closure ${ }^{8,22}$. Israeli researchers infer mean wound healing time of \pm 36.05 and \pm 69 .44 days, with an interval of 15 to 180 days in the ozone group, while in the control group the mean time was greater than 180 days $^{8}$. A study in Brazil, which evaluated the 
progress of conventional wound treatment in people with DM, identified that the median for healing time was 248 days $(\mathrm{IQ}=125-492)^{27}$. These data demonstrate the effectiveness of ozone use in tissue repair time.

There was a predominance of local application of ozone, with ozone in bags (bagging). The use of ozone in this way was successfully used by researchers from China, Israel and Cuba, through an occluded chamber, with a mixture of oxygen and ozone $\mathrm{e}^{15,16,20,22}$. The greatest preference for local application in bagging may lie in the fact that it requires simple, low-cost, safe and minimally invasive techniques, and, thus, it is more acceptable to patients.

However, there is variability in application frequency, formulation type and ozone/oxygen concentration. This reason can be related to the fact that there is a variability of protocols, but none has been disseminated as the most suitable for use in diabetic foot. Another point that can explain this situation is the fact that ozone therapy is considered a contemporary technology, which can generate the existence of a variability of tests and studies that are still in progress.

The safety of handling ozone therapy and its effects is a factor that has stimulated research in the area. A comprehensive use of options, technological innovations and the absence of side effects provide scientists with significant margins of safety. A priori, it is revealed that $\mathrm{O}^{3}$ it has no toxicological effects or influence on the structure of deoxyribonucleic acid (DNA), and no adverse reactions have been reported by clinical trials, it seems that there is no risk to patient safety ${ }^{8,18,20}$.

Highlighting the beneficial effects of ozone therapy may help nursing professionals to develop advanced practices for the treatment of foot ulcer injuries in people with DM. In Brazil, COFEN, through Resolution number 567, of January 29,2018, declares that the treatment of wounds and their assessment are the responsibility of the nurse, as well as the elaboration of protocols, selection and indication of new technologies for treatment of the condition ${ }^{28}$.

Knowing innovative adjuvant techniques is an evolutionary milestone for each field, investigating and elaborating questions is also a function that brings implementation of care, each process that generates research, produces science and entails several welcome conditions in the user's life. Despite having limitations, such as the unavailability of some studies in their entirety, this review presents promising data regarding the benefits of using ozone therapy in the treatment of foot ulcers in people with DM. The data found in this review may contribute to evidence-based practice, innovation in nursing care for people with DM and foot ulcers.

New studies are expected to show increasingly promising results on the use of ozone in the treatment of diabetic foot, frequency of application, type of formulation and ozone/oxygen concentration to validate the efficacy and safety data demonstrated in this review.

\section{CONCLUSION}

The use of ozone therapy in the treatment of diabetic foot has the benefit of progress in tissue repair, increase in granulation tissue, antiseptic and bactericidal properties, prevention or inhibition of oxidative stress, improvement in tissue vascularization, improvement in glycemic control, improvement in pain, decreased amputation rates, reduced hospital stay, reduced edema, multiplication of collagen fibers, reduced percentage of platelet aggregation and increased expression of vascular endothelial growth factor (VEGF) proteins, transforming growth factor beta (TGF- $\beta$ ) and platelet-derived growth factor (PDGF). It is noteworthy that ozone therapy points to an arsenal of therapeutic resources to accelerate the healing of foot ulcers in diabetic individuals and at a lower cost than conventional treatments.

\section{AUTHORS' CONTRIBUTION}

Conceptualization: Batista FWS, Araújo TM e Brandão MGSA; Methodology: Batista FWS, Araújo TM e Brandão MGSA; Investigation: Batista FWS e Brandão MGSA; Writing - First version: Batista FWS, Araújo TM e Brandão MGSA; Writing - Reviewing \& Editing: Batista FWS, Araújo TM, Brandão MGSA, Ponte VA; Supervision: Araújo TM e Brandão MGSA. 


\section{DATA STATEMENT AVAILABILITY}

Not applicable.

\section{REFERENCES}

1. Caixêta HFO, Gurgel TLS, Costa MDMA, Júnior JJV, Vianna ACF, Silva GR et al. Ozonioterapia no controle de infecção em cirurgia oral. ROC. 2019;3(1):37-43. https://doi.org/10.31991/v3n12019roco3

2. Ornelas PTSF, Sousa CM, Silva ICR, Fratelli CF. As evidências científicas da eficácia do uso da ozonioterapia frente à legislação sanitária brasileira. REVISA. 2020;9(2):320-26. https://doi.org/10.36239/revisa.v9.n2.p320a326

3. Projeto de Lei do Senado n. 227/2017, de 12 de julho de 2017 (BR). Autoriza a prescrição da Ozonioterapia em todo o território nacional. Brasília (DF). 12 jul. 2017. Available at: https://www25.senado.leg.br/web/atividade/materias/-/materia/130041

4. Conselho Federal de Enfermagem, Brasília. Parecer normativo n 01/2020/DF. Brasília: Cofen; 20 de fevereiro de 2020.

5. Fernandes FCGM, Santos EGO, Morais JFG, Medeiros LMF, Barbosa IR. O cuidado com os pés e a prevenção da úlcera em pacientes diabéticos no Brasil. Cad Saúde Colet. 2020;28(2):302-10. https://doi.org/10.1590/1414-462X202028020258

6. Cardoso NA, Cisneros LL, Machado CJ, Procópio RJ, Navarro TP. Fatores de risco para mortalidade em pacientes submetidos a amputações maiores por pé diabético infectado. J Vasc Bras. 2018;17(4):296-302. https://doi.org/10.1590/1677-5449.010717

7. Cho NH. International Diabetes Federation. IDF Diabetes Atlas, 9a ed. International Diabetes Federation, Belgium; 2019.

8. Izadi M, Kheirjou R, Mohammadpour R, Aliyoldashi MH, Moghadam SJ, Khorvash F et al. Efficacy of comprehensive ozone therapy in diabetic foot ulcer healing. Diabetes Metab Syndr. 2019;13(1):822-5. https://doi.org/10.1016/j.dsx.2018.11.060

9. Teuvov AA, Baziev AM, Lovpache ZN, Teunikova IS, Chudopal SM. Ozone Therapy in the Comprehensive Treatment of Diabetic Foot Syndrome. Biomed \& Pharmacol J. 2017;10(4):1871-8. https://doi.org/10.13005/bpj/1306

10. Soares JCN, Sousa AMM, Sousa SMA, Rolim ILTP. Aleitamento materno na prevenção do câncer de mama: uma revisão integrativa da literatura. REV UNINGÁ. 2019;56(S6):13-22. Available at: http://revista.uninga.br/index.php/uninga/article/ view/1032

11. Moura LR, Torres LM, Cadete MMM, Cunha CF. Factors associated with health risk behaviors among Brazilian adolescents: an integrative review. Rev Esc Enferm USP. 2018;52:e03304. https://doi.org/10.1590/S1980-220X2017020403304

12. Tostes MFP; Galvão CM. Implementation process of the Surgical Safety Checklist: integrative review. Rev. Latino-Am. Enfermagem. 2019;27:e3104. https://doi.org/10.1590/1518-8345.2921.3104

13. Ursi ES, Galvao CM. Prevenção de lesões de pele no perioperatório: revisão integrativa da literatura. Rev. Latino-Am. Enfermagem. 2006;14(1):124-31. https://doi.org/10.1590/S0104-11692006000100017

14. Melnyk BM, Fineout-Overholt E. Making the case for evidence-based practice. In: Melnyk BM, Fineout-Overholt E. Evidencebased practice in nursing \& healthcare. A guide to best practice. Philadelphia: Lippincot Williams \& Wilkins; 2005. p.3-24.

15. Gao L, Li T, Wang S, Wang J. Comprehensive treatment of diabetic hallux gangrene with lower extremity vascular disease: $\mathrm{A}$ case report. J Int Med Res. 2019;47(12):6374-84. https://doi.org/10.1177/0300060519886993

16. Martínez AF, Martínez AF, Pérez CV, Leonard DP, López AA. Evolución de las úlceras de pie diabético con el tratamiento mixto de Heberprot-P® y ozonoterapia. Rev Cubana Angiol Cir Vasc. 2019;20(1):e378. Available at: http://scielo.sld.cu/scielo. php?script=sci_abstract\&pid=S1682-00372019000100003\&Ing=es\&nrm=iso

17. Rosul MV, Patskan BM. Ozone therapy effectiveness in patients with ulcerous lesions due to diabetes mellitus. Wiad Lek. 2016;69(1):7-9. Available at: https://pubmed.ncbi.nlm.nih.gov/27162287/

18. Barrios JAL, Ravelo YA, Díaz YM, Rivero BM, Zaldivar AT. Atención multidisciplinaria con terapia avanzada y de recurso a pacientes con pie diabético en Mayabeque. Rev Cubana Angiol Cir Vasc. 2015;16(2):139-53. Available at: http://scielo.sld.cu/ scielo.php?script=sci_arttext\&pid=S1682-00372015000200003

19. Duarte HA, Carretero JH, Peña YA, Valcárcel JRG, Concepción, DR, Carbonell VGJ. Beneficios de la intervención con ozonoterapia en pacientes con pie diabético neuroinfeccioso. Rev Cubana Angiol Cir Vasc. 2014;15(1):12-21. Available at: http://scielo.sld.cu/ scielo.php?script=sci_arttext\&pid=S1682-00372014000100003

20. Zhang J, Guan M, Xie C, Luo X, Zhang Q, Xue Y. Increased growth factors play a role in wound healing promoted by noninvasive oxygen-ozone therapy in diabetic patients with foot ulcers. Oxid Med Cell Longev. 2014;2014:1-8. https://doi. $\operatorname{org} / 10.1155 / 2014 / 273475$ 
21. Fathi AM, Mawsouf MN, Viebahn-Hänsler R. Ozone Therapy in Diabetic Foot and Chronic, Nonhealing Wounds. Ozone: Science \& Engineering. 2012;34(6):438-50. https://doi.org/10.1080/01919512.2012.718700

22. Wainstein J, Feldbrin Z, Boaz M, Harman-Boehm I. Efficacy of ozone-oxygen therapy for the treatment of diabetic foot ulcers. Diabetes Technol Ther. 2011;13(12):1255-60. https://doi.org/10.1089/dia.2011.0018

23. Cardoso CC, Filho ED, Pichara NL, Campos EGC, Pereira MA, Fiorini JE. Ozonoterapia como tratamento adjuvante na ferida do pé diabético. Rev méd Minas Gerais. 2010;20 (n. esp): 442-5. Available at: https://pesquisa.bvsalud.org/portal/resource/pt/ lil-568308

24. Monte A, Zee H, Bocci V. Major ozonated autohemotherapy in chronic limb ischemia with ulcerations. J Altern Complement Med. 2005;11(2):363-7. https://doi.org/10.1089/acm.2005.11.363

25. Martínez-Sánchez G, Al-Dalain SM, Menéndez S, Re L, Giuliani A, Candelario-Jalil E et al. Therapeutic efficacy of ozone in patients with diabetic foot. Eur J Pharmacol. 2005;523(1-3):151-61. https://doi.org/10.1016/j.ejphar.2005.08.020

26. Batista AD, Mesa MG, Manresa CP, Cepero SM. Efecto del ozono sobre la activación plaquetaria en pacientes diabéticos tratados con ozonoterapia: informe preliminar. Rev Cubana Invest Bioméd. 2001;20(1):45-7. Available at: http://scielo.sld.cu/ scielo.php?script=sci_arttext\&pid=S0864-03002001000100010

27. Oliveira MF, Viana BJF, Matozinhos FP, Silva MMS, Pinto DM, Moreira AD et al. Feridas em membros inferiores em diabéticos e não diabéticos: estudo de sobrevida. Rev Gaúcha Enferm. 2019;40:e20180016. doi: https://doi.org/10.1590/19831447.2019.20180016

28. Conselho Federal de Enfermagem, Brasília. Resolução Cofen n. 567/2018. O Conselho Federal de Enfermagem - Cofen, no uso das atribuições que lhe são conferidas pela Lei $n^{\circ}$ 5.905, de 12 de julho de 1973, e pelo Regimento da Autarquia, aprovado pela Resolução Cofen n 421, de 15 de fevereiro de 2012. Brasília: Cofen; 29 de janeiro de 2018. 